University for Business and Technology in Kosovo

UBT Knowledge Center

UBT International Conference

2018 UBT International Conference

Oct 27th, 9:00 AM - 10:30 AM

\title{
Raising Risk Equity Capital Through a Private Placement Process in Emerging Markets
}

\author{
Elena Ralinska \\ University of National and World Economy, zlatin.sarastov@unwe.bg \\ Zlatin Sarastov \\ University of National and World Economy, e.ralinska@yahoo.com
}

Follow this and additional works at: https://knowledgecenter.ubt-uni.net/conference

Part of the Business Commons

\section{Recommended Citation}

Ralinska, Elena and Sarastov, Zlatin, "Raising Risk Equity Capital Through a Private Placement Process in Emerging Markets" (2018). UBT International Conference. 306.

https://knowledgecenter.ubt-uni.net/conference/2018/all-events/306

This Event is brought to you for free and open access by the Publication and Journals at UBT Knowledge Center. It has been accepted for inclusion in UBT International Conference by an authorized administrator of UBT Knowledge Center. For more information, please contact knowledge.center@ubt-uni.net. 


\title{
Raising Risk Equity Capital Through a Private Placement Process in Emerging Markets
}

\author{
Elena Ralinska and Zlatin Sarastov \\ University of National and World Economy, Sofia, 1800 Bulgaria \\ Zlatin.sarastov@unwe.bg
}

\begin{abstract}
A survey on the full cycle of raising equity capital for risky ventures in emerging markets is reviewed on the basis transactions in Bulgaria. A special emphasis is put on the particulars and specifics of the process when applied in uncertain environment and emerging markets where even the capital expenditure on project structuring and execution is very sensitive. Main pitfalls are identified and the fastest and most efficient route from time and cost perspective is suggested. Real life cases on a no-name basis are being used to review the main characteristics of the process.
\end{abstract}

Keywords: Venture capital, private placement, equity capital, placement execution 


\section{$1 \quad$ Private Placement Process}

The private placement of financial instruments with the objective to raise capital is an established practice in the developed market economies for projects and companies at early stages of their development. Although not as much regulated as initial public offerings, common standards have emerged and evolved through time. In the emerging economies the practices of raising capital through private placement is not as orderly and tends to emerge only after a well-functioning banking sector is in place. Start-up, and early stage business in such market economies tend to rely on friends, family, bank capital and business angels or high-net worth equity partners. However, when tapping such sources of finance, the development of each particular deal is self-emergent and follows its own particular logic and intricacies. Only when debt capacity is exhausted and the scale of the objectives demand greater funding (over 500,000 euro) a more orderly and organized process of raising capital emerges with the involvement of third party professionals. Professional services at the outset are provided by audit and advisory services providers, followed by legal or unregulated corporate finance practices and ultimately licensed investment intermediaries.

The Standard process post retention includes the following stages (1) concept and business model definition (2) information gathering (3) financial modelling, valuation and deal structuring (4) information memorandum and synopsis drafting, (5) composition of a list of potential investors (6) investor approach phase (7) preliminary negotiations with interested investors (8) memorandum of understanding drafting and signing (9) due diligence (10) contract negotiation and signing (11) contract execution and (12) deal Closing, (DePamphilis, 2015).

\section{Objectives, Scope and Design of the Present Study}

Access to data is very restricted due to the competitive nature of the advisory and investment intermediary business and was secured on the basis of networking relations as pointed also by Huang (2008). A particular challenge is to convince the data sources of the strictly scientific nature of the objectives of the study as many of the scholars in economics tend to involve in practicing this trade professionally in addition to their academic involvements.

In order to identify and analyze the main characteristics of the private placement process we have studied 45 particular cases obtained from 7 third party advisors of which 18 successful, all of them in Bulgaria, during the period 2012-2017, in the high-tech, information and computer technologies sectors of Bulgaria. Success is defined as being able to raise at least $30 \%$ of the initially intended amount. The sources of primary information are documents from and discussions with investment intermediaries and advisory practices. All of the cases can be classified as early to intermediate stage finance, where the business model has already been defined and product or service has been developed. We have deliberately omitted cases of seed or acceleration finance, as these 
lack the order and organization enabling us draw relations, generalizations and conclusions. The target funding ranged between 0.5 and 3.5 million euro with a mean of 1.35 million euro. The information is commercially sensitive and has been disclosed to us under the conditions of privacy and hence the analysis provided by us in on a no-name basis.

\section{$3 \quad$ Key Observations and Discussion of the Results}

Table 1. Sample characteristics

\begin{tabular}{lcccc}
\hline & $\begin{array}{c}\text { Length of the } \\
\text { process /in } \\
\text { months/ }\end{array}$ & $\begin{array}{c}\text { Target level } \\
\text { /mil. Euro/ }\end{array}$ & $\begin{array}{c}\text { Success } \\
\text { fee }\end{array}$ & $\begin{array}{c}\text { Retained amount } \\
\text { /mil. Euro/ }\end{array}$ \\
\hline Max & 18 & 3.5 & $10 \%$ & 27500 \\
Min & 9 & 0.5 & $2 \%$ & 8000 \\
Mean & 13.1 & 1.4 & $4 \%$ & 11887 \\
Mode & 10 & 1 & $4 \%$ & 8000 \\
Median & 13 & 1.1 & $4 \%$ & 11000 \\
\hline
\end{tabular}

\subsection{Length of Process}

On the basis of the sampled cases, the process of capital raising lasts between 9 months and 18 months with a mean of 13.1 months and median 13 . We define the start date to be the date of retention of investment intermediary and the end date to be the signing of a mutually binding contract. We have branded as unsuccessful processes that ended up with a non-binding Memorandum of Understanding and then protracted or entered a lengthy modification process and ended up in a funding with a structure materially different from the initial intentions.

\subsection{Retention of Advisors}

Our main points of interest are scope of assignment, compensation and alignment of interests. As we restricted the topic of the study to private placements the scope question reduces to variations within this particular theme. Nearly two thirds of all cases had a well elaborated business concept and model before initiation of the private placement process. Sixty percent of these however had to undergo significant modification on the basis of feed-back or negotiation process with a lead investor in the process. The remaining cases lacked sufficient clarity and required significant input from the retained advisor. Of all cases studied only eight had an elaborate business plan and four had a standard generally accepted DCF model in place before retention of external placement agents and advisors. In all studied cases however, the scope of the initial 
engagement included all standard parts of a placement process: (1) Financial Model, (2) Transaction structuring (2) Information Memorandum, (3) Synopsis, (4) Memorandum of Understanding. Three transactions evolved in a number of consecutive assignments that constitute a whole private placement cycle. Eight of the cases included provisions for subsequent involvement in the execution process such as Data Room preparation, Due-Diligence assistance and organization. Final Agreement negotiation participation was included in $15 \%$ percent of initial advisor retention arrangements. The remuneration in 4 of the cases was success based only with no upfront fees for purely advisory services such as financial model, deal structuring or document preparation. The success-related element of compensation was not present in only two of the cases, where apparently the sponsor already had a list of committed potential investors. The remaining engagements included a mixed compensation scheme with a fixed element and a success fee either as percentage of capital raised or again an absolute amount. Based on the sample the fixed sum for retention ranged from 8,000 to 27,500 euro with the mean being 11,878 euro, median 11,000 and the most common 8,000 euro all net of VAT. The success fee ranged between $1.5 \%$ and $10 \%$ with mean of $3.9 \%$ and equal median and mode of $4 \%$.

Table 2. Overview of sample characteristics

\begin{tabular}{lccccc}
\hline & Projects & DCF model developed & $\begin{array}{c}\text { Information } \\
\text { memorandum } \\
\text { prepared }\end{array}$ & $\begin{array}{c}\text { Business plan } \\
\text { prepared }\end{array}$ & Synopsis \\
\hline Successful & 18 & 37 & 18 & 33 & 33 \\
Unsuccessful & 27 & 8 & 27 & 12 & 12 \\
\hline
\end{tabular}

\subsection{Financial Model and Valuation}

Eight of the cases were not supplied with a standard discounted cash flow model, but based their valuation on comparable methods, also known as multiples-based valuations. The rest had a standard DCF valuation model of which 23 complied with the best globally accepted practices. Koller et al. (2010). Six of the multiples' valuations were based on forward looking EBITDA or EBIT estimates, with the remaining citing reported figures as already in business. The DCF models included forecasts of the Income Statement, the Balance Sheet and The Cashflow Statement. The horizon of the forecasts ranged between 3 and 20 years with the most common being 10 years of forecasts. Sixteen cases relied on CAPM based cost of capital estimation with some country risk modifications. Seven of the cases applied hurdle rates with three explicitly taking into account the specific risk into the discount formula denominator.

\subsection{Synopsis}

The synopsis is short document whose main purpose is to generate initial interest in the prospective transaction. In the usual setting it is prepared only after the completion of the investment memorandum. However, two thirds of the cases started contacting investors on the basis of a financial model and synopsis only with the idea to complete 
the information memorandum only after an investor interest is demonstrated. This is be typical for high-tech and ICT sector as there is a great deal of uncertainty regarding the success of a capital raising initiative (Carpentier, 2005). All of the 45 cases had the equivalent of a capital raising summary, synopsis or a teaser with 37 explicitly branding the document as being such. The length of this document ranged from 2 to 7 standard pages, averaging 3.2 and included the standard elements as described by DePamphilis (2015).

\subsection{Information Memorandum}

The information memorandum is the document that serves as the main information source regarding a capital raising through private placement transaction. This document also usually contains the data from the financial model if one had been prepared. Unlike most of the IPO prospectuses, the private placement memorandum can contain forward looking estimates and all the ones reviewed by us contained such estimates.

Although only 18 of the cases had a document explicitly branded as information memorandum we regard that 28 cases reached information memorandum distribution stage, as the business plan serves that purpose. The remaining cases had not generated sufficient investor interest to justify the preparation of a detailed information memorandum. In twelve of the 28 cases the document was termed information memorandum, with the remaining using a standard business plan, the main difference being that a business plan did not include a proposed deal structure and an explicit deal offer component. The topics that existed in all the documents that performed the function of an investment memorandum covered the standard topics of investor interest and effect on value (DePamphilis 2015).

\subsection{Shortlisting and Contacting Potential Investors}

The shortlisting process included desktop studies and access of data bases. $16 \%$ of the offerings targeted both strategic and financial investors with the remaining 38 cases targeting only financial investors. The percentage of leads originating from project sponsor ranged between $22 \%$ and $41 \%$ with the remaining attributed to the financial advisor. The investor contacting ranged in duration between two and four months until either the capital raising initiative was abandoned or investor interest was generated. Most of the sell-side participants in the process, sponsors and advisors alike consider a private placement not worth continuing if interest is not generated within 3 months from the start of the offering. The advisors usually start from the top of the list where the most likely potential investors are positioned and continue down as far as considered worthwhile. The latter is utterly discretionary and based on intuition or feed-back from initially contacted prospective investors (Reeve 2016).

\subsection{Memorandum of Understanding}

Only 15 of the 22 cases that reached this point in the process were furnished with a signed Memorandum of Understanding document. This is a non-binding document and 
serves only as a temporary negotiation mile-stone to fix the terms before a costly and time-consuming due-diligence stage is entered into. Because of its non-binding nature or probably because parties were eager to retain flexibility or required additional information or assurances in 7 of the 22 cases such a document was not negotiated or signed between the parties.

\subsection{Process Abandonment}

Just over one third of the 27 unsuccessful offerings failed to generate valid interest, 13 were dropped at the stage of initial review before reaching due diligence (the prospective investor having received an IM), 2 were abandoned in the course of a more serious due-diligence effort either formal or informal. This means that of all of the 22 projects that reached due diligence stage 20 managed to pass through this hurdle with remaining 2 failing at the final terms and conditions negotiations. Investors are doing most of the assessment before the due diligence phase.

\subsection{Due-Dilligence Process}

Just under half of the cases from the sample reached due diligence phase. In 14 of the 22 cases the process was formalized and structured with the corresponding rules and procedures in place. These being high-tech and ICT sector companies the data room that is normally a location for assembly and access for verification of all facts and estimates based in the information memorandum took the form of a controlled access and manipulation directory in a virtual cloud service. The due diligence process ranged in duration from two and a half weeks to 8 weeks with the average being just over a month.

\subsection{Negotiation and Deal Signing}

The length of the contract negotiation phase span from 3 to 14 months with the average being 5.4 months. Two of the cases surviving till this stage were abandoned. The negotiations in 6 of the cases, slightly less than $1 / 3$, that reached this stage resulted in a structure significantly differing from the one set out in the Memorandum of Understanding.

\section{Conclusion}

The process is different from the usual in developed markets. It is less orderly but more flexible with frequent escapes from the standard route. The main concerns of the sponsors and advisor are costs and efficiency and probability of success. The sponsors are very reluctant to commit to fixed up-front fees and look to shift the weight of the compensation towards the success element. The process is evolving and improving with increasing number of transactions each year within the studied period and the involvement of leading global practices mostly on the buy-side. We have not held interviews 
with sponsors of capital-raising projects but advisors only and hence can conclude on their concerns or perceptions only indirectly. The main concern of sponsors is the justification of the fixed costs with regards to the likelihood of success. The sponsors also attempt to stage remuneration and insist on flexibility and being able to walk out of the process if investor feed-back is not positive. A great deal of further research is required in order to sufficiently characterize the process with the main restriction being availability of and access to information.

\section{References}

1. Carpentier, C. et al.: The Costs of Issuing Private Versus Public Equity. Cirano, Montreal (2005).

2. Reeve, L.: Private Placement Market Investor Survey. EY, London (2016).

3. DePamphilis, D.: Mergers. Acquisitions and Other Restructuring Activities. 8th edn. Elsevier, Ofxord (2015).

4. Huang, R.: The Networking Function of Investment Banks, Kenesaw (2008).

5. Koller, T., Goedhart, M., \& Wessels, T. (2010). Valuation, Measuring and managing the value of companies. Hoboken, New Jersey: John Wiley \& Sons. 